va E. S., Grigoryev I. P., [et al.] Teoreticheskiye osnovy i prakticheskoye primeneniye metodov immunogistokhimii: ruk-vo pod red. D. E. Korzhevskogo. Spec.Lit., 2014.

7. Lundberg J. O., Weitzberg E. Biology of nitrogen oxides in the gastrointestinal tract. Gut. 2013;62(4):616-629. doi: 10.1136/gutjnl-2011-301649

8. Magnesium in the Central Nervous System. Edited by $R$. Vink, M. Nechifor. Adelaide: University of Adelaide Press, 2011, 355. doi: 10.1017/UPO9780987073051

9. Okabe S., Miyake H., Yamasaki S. Effects of NC-1300, a gastric proton pump inhibitor, on healing of acetic acid-induced gastric ulcers in rats. Digestive Diseases and Sciences. 1989;34(7):1035-1042. doi: 10.1007/ BF01536370

10. Raghavan S., Holmgren J., Svennerholm A.-M. Helicobacter pylori Infection of the Gastric Mucosa.
Mucosal Immunology. 2015;1-2:985-1001. doi: 10.1016/B978-0-12-415847-4.00051-3

11. Rogova L. N., Shesternina N. V., Zabolotneva K. O. Staravoytov V. A. Agressivnye faktory i mekhanizmy zashchity tkaney zheludochno-kishechnogo trakta, ikh rol v patologii. Volgograd: Publ. house «VolgGMU», 2014.

12. Sung J J Y Kuipers E J., El-Serag H. B Systematic review: The global incidence and prevalence of peptic ulcer disease. Alimentary Pharmacology $\begin{array}{ll}\text { and } & \text { Therapeutics. }\end{array}$ doi: 10.1111/j.1365-2036.2009.03960.x

13. Zabala T. B., Lucero Y, Lagomarcino A. J., OrellanaManzano A., George S. [et al.] Review: Prevalence and dynamics of Helicobacter pylori infection during childhood. Helicobacter. 2017;22(5):e12399. doi: 10.1111/hel.12399

About authors:

Rogova Lyudmila Nikolaevna, DMSc, Professor, Head of Department of Pathophysiology. Clinical Pathophysiology; tel.: +78442385364

Povetkina Victoria Nikolaevna, CMSc, Associate Professor of Pathophysiology. Clinical Pathophysiology; tel.: +78442385364

(C) Group of authors, 2017

UDC 616.314.17-008.1:538.3

DOI - https://doi.org/10.14300/mnnc.2017.12095

ISSN - 2073-8137

\title{
THE EFFECT OF MAGNETOPHOTOTHERAPY ON MORPHOLOGICAL CHANGES OF TISSUES OF PATHOLOGICALLY CHANGED PERIODONTIUM
}

Rubnikovich S. P. ${ }^{1}$, Maizet A. I. ${ }^{1}$, Denisova Yu. L. ${ }^{2}$, Bykova N. I. ${ }^{3}$, Arutyunov A. V. 'ं, Kopylova I. A.' 4 , Avanesyan R. A. ${ }^{4}$

1 Belarusian Medical Academy of Postgraduate Education, Minsk, Republic of Belarus

2 Belarusian State Medical University, Minsk, Republic of Belarus

3 Kuban State Medical University, Krasnodar, Russian Federation

${ }^{4}$ Stavropol State Medical University, Russian Federation

\section{ВАИЯНИЕ МАГНИТОФОТОТЕРАПИИ НА МОРФОАОГИЧЕСКИЕ ИЗМЕНЕНИЯ ТКАНЕЙ ПАТОАОГИЧЕСКИ ИЗМЕНЕННОГО ПЕРИОАОНТА}

С. П. Рубникович ${ }^{1}$, А. И. Майзет ${ }^{1}$, Ю. А. Аенисова ${ }^{2}$, Н. И. Быкова ${ }^{3}$,

А. В. Арутюнов ${ }^{3}$, И. А. Копылова ${ }^{4}$, Р. А. Аванесян ${ }^{4}$

1 Белорусская меАицинская акаАемия послеАипломного образования,

Минск, Республика Беларусь

2 Белорусский госуАарственный МеАицинский Университет, Минск, Республика Беларусь

3 Кубанский госУАарственный МеАицинский Университет, КрасноАар, Российская ФеАерация

${ }^{4}$ Ставропольский госуАарственный меАицинский университет, Российская ФеАерация

The effect of a low-intensity magnetic field combined with polarized light on the microvasculature links in periodontal tissues during orthopaedic treatment by fixed dentures in patients with partial secondary adentia and periodontal diseases were determined using an experiment on laboratory animals. The experiment was made on selected 107 random-bred rats. The animals were divided into three groups: control group 1, control group 2, and the experimental group. A dynamic analysis of morphological changesin the tissues of pathologically changed periodontium in three groups of animals demonstrated that, as compared to other animals, the rats from the experimental groups, following experimental magneto phototherapy, had early elimination of inflammation (1 hour after termination of the impact) in all gingival components and perifocal structures due to vaporization of inflammatory cells, activation of vessels (plethora and a noticeable increase in number), while regeneration and full epithelialization of the gingival pocket were completed 2 days after termination of magneto phototherapy.

Keywords: partial secondary adentia, periodontal diseases, magneto phototherapy, animal studies

Представлены результаты экспериментального исследования по изучению влияния низкоинтенсивного магнитного поля в сочетании с поляризованным светом на звенья микроциркуляторного русла в тканях периодонта на 107 рандомбредных крысах. Динамический анализ морфологических изменений в тканях патологически измененного периодонта в трех группах животных показал, что по сравнению с остальными животными 
у крыс в экспериментальной группе под влиянием магнитофототерапии в эксперименте происходит ранняя элиминация воспаления (через 1 час после прекращения воздействия) во всех компонентах десны и перифокальных структурах за счет вапоризации воспалительных клеток, активация сосудов (полнокровие, заметное нарастание их количества), а регенерация и полная эпителизация десневого кармана была завершена через 2 суток после прекращения воздействия магнитофототерапии.

Ключевые слова: частичная вторичная адентия, болезни периодонта, магнитофототерапия, исследования на животных

\section{$\mathrm{T}$} he efficacy of comprehensive treatment of patients with periodontal diseases depends on the use of additional treatment and prevention interventions.Application of physical factors for comprehensive treatment of inflammatory diseases is an important part of comprehensive treatment. The use of physical factors at different stages of a disease makes it possible not only to eliminate the initial signs of the pathological process, but also to reduce the intensity of its clinical manifestation and the probability of relapse, thereby giving the most optimal treatment outcomes [3, 4, 9, 12].

Combined or supplementing physiotherapeutic treatment of periodontal diseases provides a number of advantages: potentiated action of several factors has a more obvious therapeutic effect; reducing the intensity and duration of the procedures and of the course of treatment; and mutual action of the physical factors at the biological, physical and physico-chemical stages of their effect $[1,6,11]$.

Magneto phototherapy causes analgesic and hypotensive effects, as well as pronounced antiedemic and anti-inflammatory actionin the tissues. The action and efficacy of magneto phototherapy are defined by physiological and curative effects of combined physical factors, i.e., light and magnetic field, on one hand, and by the interaction of these factors and the shifts induced in the body, on the other hand.

The use of magneto phototherapy at different stages of dental treatment stimulates biosynthetic processes and generation of phosphates rich in energy, enhances regional circulation and microcirculation, stimulates erythropoiesis, decreases aggregation of blood platelets, enhances oxygen capacity of blood, etc. Combined use of magnetic field and phototherapy causes magneto photoelectric effect (Kikoin-Noskov effect), inducing a powerful electromotive force in the tissues. Magnetic fields facilitate deep penetration of optical radiation into the tissues and increase the range of optical radiation perception by the cells. Magnetic fields cause the splitting of energy levels and spectral lines of atomic systems in the tissues, thereby imparting them additional energy (Zeeman effect). Combined effect of light and magnetic field enhances each of the factors and increases the total therapeutic activity of the method [5, 14].

The goal of the research was to study the character of morphological changes in the tissues of pathologically changed periodontium after exposure to magneto phototherapy in animal testing.

Material and Methods. In order to reach this goal, the experiment included 107 random-bred rats of both sexes, 209-243g of body weight, divided into 3 groups.

All animals were kept in absolutely identical conditions: they were given regular diet in the vivarium for $45-52$ days It was proven that after "suppression of the freedom reflex» the rats, kept on a regular diet in the vivarium, developed periodontitis (spontaneous periodontitis) that can be used as a model for a similar disease in humans [8, 10, 13].

During the experiment, all testing was made in conformity with the rules for experimental animals fully complying with all principles of bioethics for anesthetized animals $[2,7]$. General anaesthesia was made using a mixture of $1 \mathrm{ml}$ of $0.005 \%$ fentanyl solution and $2 \mathrm{ml}$ of $0.5 \%$ droperidol solution. Following anaesthesia, the an- imals were fixed on their back in special equipment for rapid standardized manipulations.

Control group 1 (5 random-bred rats) was used to study periodontal tissues in order to define the condition of the healthy gum, followed by pathomorphological evaluation of the healthy gum biopsy material.

Control group 2 (42 random-bred rats) included laboratory animals with experimentally induced periodontitis, for which no magneto phototherapy was used, followed by pathomorphological evaluation of the biopsy material.

The exponential group (60 random-bred rats) included laboratory animals with experimental periodontitis, for which magneto phototherapy was applied, followed by pathomorphological evaluation of the biopsy material directly after physical impacts, after 1 hour, 2 hours, 3 hours, as well as every day from day 1 to day 8 after treatment. Also, the character of pathomorphological changes in the tissues of pathologically changed periodontium after magneto phototherapy was determined.)

Physical impact was exerted on the gum area, the mandibular central incisors of animals with periodontitis. Magneto phototherapy was performed using a device for magneto phototherapy with magnetic field induction from 15 to $25 \mathrm{MT}$, the radiation wavelength from 460 to $960 \mathrm{~nm}$, and the radiation flow power from 1.5 to $4.5 \mathrm{~mW}$.

The experiment was terminated, upon completion of the period of animals observation (the experimental group andcontrol group 2), by instant decapitation after intraperitoneal thiopental narcosis administered as $1 \mathrm{ml}$ of $5 \%$ thiopental sodium per 100 grams of the body weight, abiding by the principles of bioethics (according to GLP). The material for microscopy studies was taken immediately after magneto phototherapy, and after 1, 2 and 3 hours, as well as each day from day 1 to day 8 after treatment. The obtained micro preparations were tested, and their micro photos were produced by a DMLS microscope with software (Leica, Germany).

Results and Discussion. The control group. The morphological studies demonstrated that the condition of periodontal tissues was within the norm during the experimental observation periods. The microscopic structure of the hum was identical in all rats studied in this group. Keratinized stratified squamous epithelium (KSSE) of the gingival crevice and the free part of the gum is, basically, uniformly thin, with thickened spots, mostly in the free part of the gum, and stratified. The epithelial ridges were predominantly wide and low, some of them thin and elongated, which forms the relevant microstructure (papillary layer) of the gum lamina propria (LP). The gingival crevice was narrow and short. The gum LP represented non-structured connective tissue (CT), loose in the papillary layer, and a loosely delimitated net-like layer of the non-structured CT and bulky collagen fibres (CFs).

Control group 2. One day (subgroup I) after termination of the stress impact, the microscopic changes of the gum were similar in all studied rats. In the mucoperiosteal flap of the animals, changes in the gingival crevice epithelium (uneven thickness with segmental elimination of the layers, dystrophy and cytolysis of the basal cells, few elongated cells of the granular layer with single dust granules, transformation of its cells to keratinocytes and 
formation of the cornified layer) were observed. Intensive purulent proliferative inflammation with destruction and separation of the junctional epithelium was found and, as a consequence, noticeable deepening of the gingival crevice and formation of the gingival pocket, periosteal microabscess, puss accumulation and purulent detritus in the deepened and expanded gingival crevice, inflammation spreading to the gum LP, the periosteum of alveolar process of the jaw bone, and the periodontal ligament.
It was observed that the LP of the free segment of the gum included small spots of proliferative inflammation, abundant slit-like lymph capillaries (optically empty), non-functioning few blood capillaries (without blood components in the lumen), with thickened walls and dystrophy of endotheliocytes. The gingival epithelium had smoothed papilla of the basal layer.

On the $2 d$ day (subgroup II), the morphological indicators matched the same indicators of subgroup I (Fig. 1A).
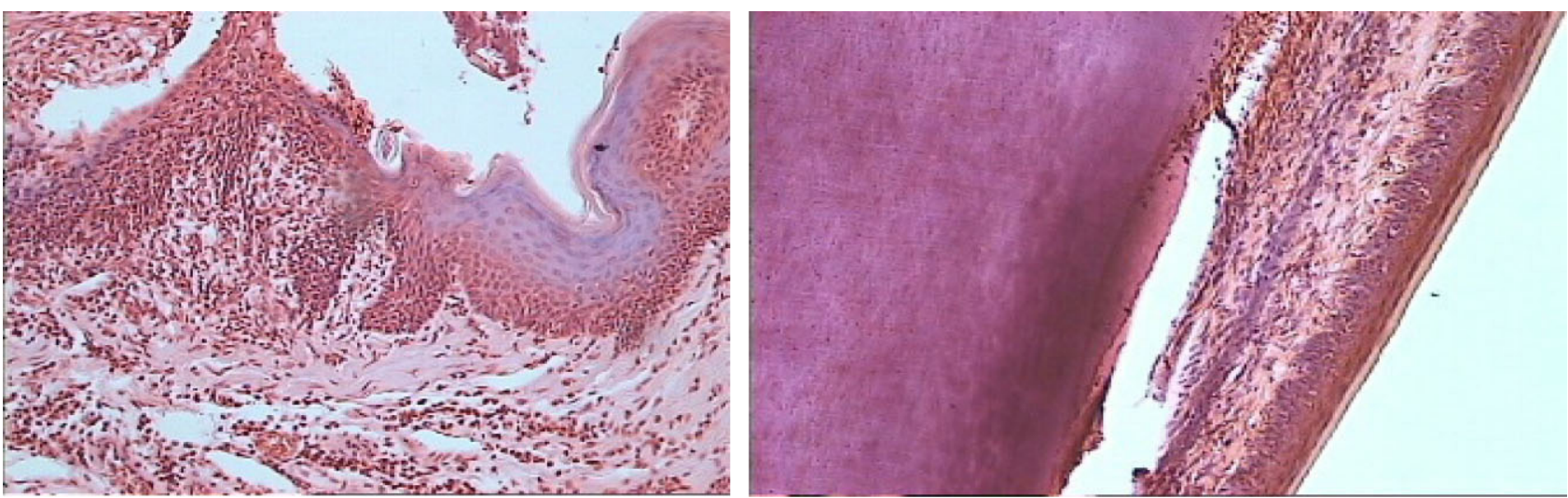

Fig. 1. The morphological changes of periodontium tissues in experimental animals the $2 \mathrm{~d}$ day aftertermination of the stress impact (A), exposure to magneto phototherapy (B). A - Small proliferative inflammation spots in the gum LP.

$B$ - No signs of inflammatory infiltration. Stained with haematoxylin and eosin. Magnification factor 200X

On the 8th day (subgroup VIII), a deep gingival crevice with inhomogeneous gingival epithelium, mostly thin with segmental destruction of the surface layers, was observed. In its middle and end, an expressed elongation of epithelial ridges was observed, with disorientation and growth into the gum LP. In the distal part, the beginning focal regeneration of epithelium with disordered arrangement of cells, cytolysisof the epithelial cells at the crevice bottom with exposure of the gum LP (ulceration), and a focal growth of the maturing granulation tissue in this area with signs of serous inflammation were visualized.

Relatively bulky spots of a similar granulation tissue inside the periodontal ligament were identified with sharply expressed hyperplasia of the cell component of the latter. In the apical segment of the free part of the gum, SSE dystrophy and surface erosion with a small spot of lymphocytes and signs ofepithelialization were identified. Slight oedema of the gum LP, focal dilated and merging optically-empty thin-wall lymphatic vessels, diffusely scattered cells compressed minor and plethoric capillaries with few blood components (up to $10-15$ in the field of microscope with 200X), small spots of perivascular lymphocyte penetration, and pockets of ectatic and plethoric venules in the gingival crevice bottom were visualized (Fig. 2A).
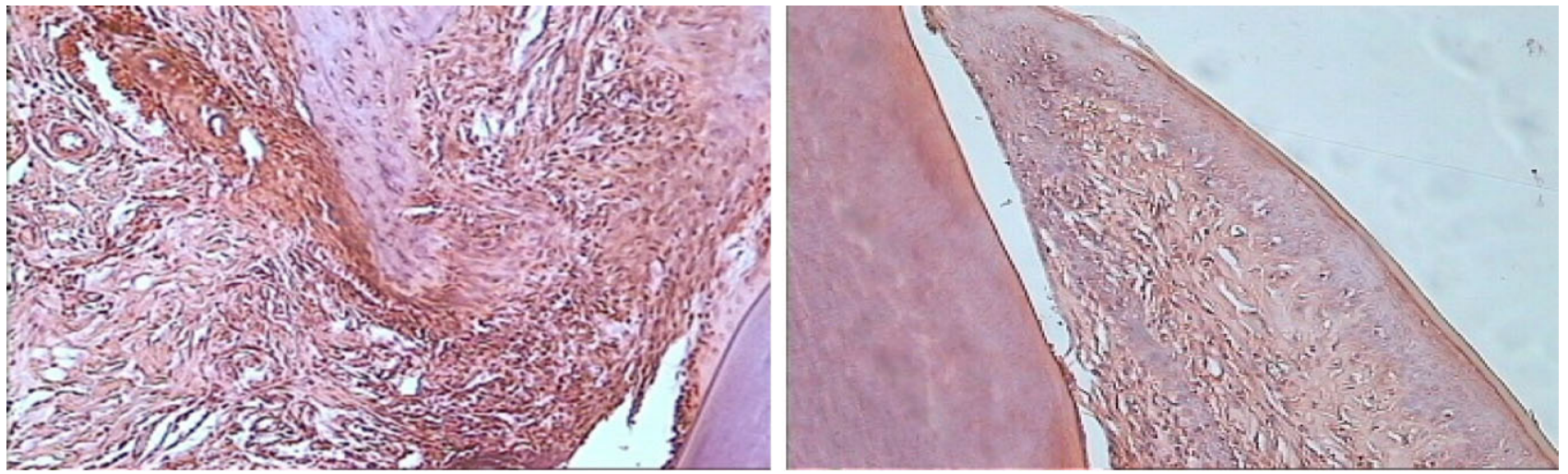

Fig. 2. The morphological changes of periodontium tissues in experimental animals the 8th dayafter termination of the stress effect (A), after magneto phototherapy (B). A - SSE dystrophy and cytolysis, and slight oedema. B - SSE of the free part of the gum contained, as in the control, glittering, granular, spinous and basal layers, without epithelial ridges. Stained withhaematoxylin and eosin. Magnification factor 200X

The experimental group. Microscopic structures of the gum in all tested rats were identical within each subgroup.

One hour after magneto phototherapy (subgroup II $E)$, SSE cornified layer was not visualized (pre-coagulation changes), glittering and uniformly thin. Singular vacuolar (vaporization) cells were found in the spinous layer, and pre-coagulation changes of SSE cells remained Total elimination of inflammatory lymph from the gingival pocket and formation of dense fibrous tissue on the edge of the gum SSE defect in the distal part and the gingival pocket bottom was present. Disseminated vaporization of inflammatory cells of the gum LP was seen, with destroyed (coagulation and pre-coagulation changes) in a 
small area perifocal of the bottom and the inner edge of the gingival pocket and on the border of the periodontal ligament.

The periodontal ligament and the splenial bony tissue of the alveolar process of the lower jaw bone are intact without inflammatory infiltration.

After 2 hours (subgroup III - E), cornified layer was not observed, and the glittering layer remained in some segments. SSE was homogeneous; restoration of the cell structure and layers was beginning, with few vacuolar epithelial cells found in the granular and spinous layers. In the gingival pocket, fragments of coagulated inflammatory cells and sections of destroyed (vaporization) hair shafts were present. The edge of the gingival pocket is surrounded by loose fibrous tissue with adjacent (adhesive) fragments of coagulated inflammatory infiltration. In the gum LP, inflammatory infiltration of the tissue component was not observed; however, ectasia and plethora of blood capillaries, as well as of lymph capillaries with retention in the lumen of lymphocytes and eosinophilic leukocytes that did not move over the wall were seen.

After 3 hours (subgroup IV - E): SSE cornified layer was not present; a segmental narrow strip of the glittering layer was observed; SSE of the gum was homogeneous; restoration of the cell structure, and singular ridges in the tip of the free edge and few cells or cells in the form of short vacuole-type bundles (vaporization) in the granular and spinous layers were identified. In the gingival pocket, coagulated inflammatory infiltration fragments, minor spots of destroyed (coagulation and pre-coagulation changed) inflammatory cells and numerous sections of destroyed (vaporization) hair shafts were visualized. Epithelialization of the gingival pocket edge for 2/3 its length was observed; it was surrounded by a narrow fibrous bundle in the bottom area.

No inflammatory infiltration of the tissue component was observed in the gum LP. Ectasia of blood and lymphatic vessels was identified, as well as retention of blood/lymph cells in their lumen that did not move beyond their wall.

After one day (subgroup $V-E$ ), SSE of the external edge in the free part of the gum had uniform thickness and contained a glittering layer; cornified layer was not observed. Weak hyperplasia of the basal layer cells was identified in some places, without epithelial ridges. The gingival pocket was narrow without any content, and its bottom represented a narrow strip of small-cell LP with homogeneous thick and pale stained CFs. The internal edge of the free and separated part of the gum was surrounded by a narrow bundle of scattered and disordered epithelial cells. The LP represented homogeneous thickened and pale stained CFs. Ectasia of lymph capillaries was observed as well as retention of a few mononuclear cells in the lumen that did not move beyond their wall.

\section{References}

1. Akhmedov G. D. Hemodynamic and regenerative efficacy of magnetic therapy in the postoperative period of dental implantation. Institut Stomatologii. 2011;3:62-64.

2. Anaesthesia of Experimental Animals: Methodological Recommendations. Moscow, 1985.

3. Bazylev N. B., Rubnikovich S. P. Investigation of the stressed-strained state of cermet dentures using digital laser speckle-photographic analysis. J. of Engineering Physics and Thermophysics. 2009;82(4):789-793.

4. Dedova L. N., Denisov L. A. The treatment of apical periodontitis by using combined exposure to focal measured vacuum and local d'Arsonval treatment. Stomatologiya. 1991;1:26.

5. Dedova L. N. Morphological characterization of the experimental periodontium. Stomatologicheskii Zhurnal. 2005:3:12.
On the $2 d$ day (subgroup $V I-E$ ) after termination of magneto phototherapy, a uniform thin glittering epithelial layer was visualized, with out cornified layer. SSE of the free edge of the gum had moderate thickness with clear cellular and layer differentiation; the granular layer was thick in some spots. The gingival pocket was without any content, its edge was epithelialized over its entire length, and epithelium was represented by a narrow bundle with disordered epithelial cells. The gum LPincluded compactly packed CFs, with no signs of inflammatory infiltration; retention of a few (1 or 2) mononuclear cells in the lumen of lymph capillaries that did not move beyond their wall was observed (Fig. 1B).

On the 8th day after magneto phototherapy (subgroup $X-E)$,SSE of the free edge of the gum contained, as in the control group, glittering, granular, spinous and basal layers were present, without epithelial ridges. The gingival pocket was narrow without any content. The gingival pocket edge was surrounded by a relatively narrow SSE strip, in some places with a relatively broad granular layer and a narrow layer of spinous and basal cells; without a glittering layer or epithelial ridges in some spots. The fixing area was represented by a narrow strip of dense fibrous tissue and a narrow strip of loose fibrous tissue.

The gum LP included densely packed CFs, chains of dilated sinusoidal lymph capillaries, small spots and strips of retention of a few mononuclear cells in the lymph capillaries without signs of inflammation (Fig. 2B).

Conclusions. Specific microscopic changes of the gum and their trends, noticeably differing from the gum microscopic structure in rats of the control group and the experimental group, were found:

Dynamic changes in the gum microscopic structure were observed 1 hour after the exposure and included total elimination of inflammatory lymph of the gingival pocket and inflammatory cells of the gum LP, or remaining precoagulation changes; after 2 hours they included signs of beginning regeneration of the gingival pocket (delimitated by a narrow bundle of mature fibrous tissue); after 3 hours, restoration of the cell structure of the gum epithelium, partialepithelialization of the gingival pocket, which was more obvious after 1 day and almost full after 2 days.

Ectasia (and plethora) of the blood and lymph sinusoidal capillaries of the gum LP with mononuclear cells retention in the latter was observed after 3 hours, with a moderate growth of intensity during the subsequent observation periods; this sign remaining up to 8 days.

Thus, early elimination of inflammation ( 1 hour after termination of the impact) in all gum components and perifocal structures due to vaporization of inflammatory cells, activation of vessels (plethora and a noticeable increase in number) was found after the exposure to magneto phototherapy, while regeneration and complete epithelialization of the gingival pocket completed 2 days after termination of magneto phototherapy.

6. Denisov L. A., Dedova L. N. Vacuum d'arsonvalization in the treatment of periodontitis. Voprosy Kurortologii, Fizioterapii i Lechebnoi Fizicheskoi Kultury. 1982;2:26.

7. Denisov S. D., Morozkina T. S. Requirements to a scientific experiment on animals. Zdravookhranenie. 2001;4:40.

8. Denisova Yu. L., Vladimirskaya T. E. Experimental justification of the use of vacuum UVR therapy in comprehensive treatment of patients with periodontitis combined with $\mathrm{c}$ dentition abnormalities and deformations. Meditsinskii Zhurnal. 2012;3:70-74.

9. Denisova Yu. L., Bazylev N. B., Rubnikovich S. P. [et al.] Laser speckle technology in stomatology. Diagnostics of stresses and strains of hard biotissues and orthodontic and orthopaedic structures. J. of Engineering Physics and Thermophysics. 2013;86(4):940-951.

10. Denisova Yu. L., Vladimirskaya T. E. Experimental justification of vacuum laser therapy in comprehensive 
treatment of patients with periodontitis combined with c dentition abnormalities and deformations. Voennaya Meditsina. 2013;1:103-107.

11. Rubnikovich S. P. Use of digital dynamic speckle anemometry for diagnosis of the surface blood flow in the mouth cavity tissue. Stomatologicheskii Zhurnal. 2007;3:26

12. Rubnikovich S. P., Bazylev N. B., Fomin N. A. New possibilities of investigating blood flow in soft tissues of the mouth. J. of Engineering Physics and Thermophysics. 2008;81(3):533-543.

13. Rubnikovich S. P., Vladimirskaya R. E., Shved I. A. [et al.] Simulation of experimental periodontitis in animals. Meditsinskii Zhurnal. 2011;1:97-101.

14. Voichenko N. V. Comparison of magneto and magneto phototherapy in experimental arthritis. Novosti Mediko-Biologicheskikh Nauk. 2012;2:129-136.

\begin{abstract}
About authors: tel.:+375296372156; e-mail: rubnikovichs@mail.ru tel.: +375295526139; e-mail: supermaz@mail.ru tel.: +79181487866; e-mail: bikov_mi@mail.ru

Rubnikovich Sergey, MD, PhD, Head of Department of Prosthodontics and Orthodontics with the course of Pediatric Dentistry;

Maizet Andrey, MD, PhD, Assistant Professor of Prosthodontics and Orthodontics with the course of Pediatric Dentistry;

Denisova Yuliya L., MD, PhD, Professor of the $3^{\text {rd }}$ Department of Therapeutic Dentistry; tel.: +375296104321; e-mail: denisova_yul@mail.ru Bykova Natalia, MD, Associate Professor; Department of Child Dentistry, Orthodontics and Maxillofacial Surgery;

Arutyunov Armenak, MD, PhD, Professor of Department of Therapeutic Dentistry; tel.: +79180343332; e-mail: armenak@mail.ru

\title{
ANALGESIC ACTIVITY OF NEW DERIVATIVES OF QUINAZOLINONE-4
}

\author{
Manvelyan E. A. ${ }^{1}$, Manvelyan M. M. ${ }^{1}$, Codonidi I. P. ${ }^{2}$, Oganesyan E. T. ${ }^{2}$ \\ 1 North-Caucasus Federal University, Stavropol, Russian Federation \\ 2 Pyatigorsk Medical and Pharmaceutical Institute, a branch of Volgograd \\ State Medical University, Russian Federation
}

\section{АНААЬГЕЗИРУЮЩАЯ АКТИВНОСТЬ НОВЫХ ПРОИЗВОАНЫХ ХИНАЗОАИНОНА-4}

\author{
Э. А. Манвелян ', М. М. Манвелян ', И. П. Кодониди ${ }^{2}$, Э. Т. Оганесян ${ }^{2}$ \\ 1 Северо-Кавказский фелеральный университет, Ставрополь, Российская Фелерация \\ 2 Пятигорский меАико-фармацевтический институт - филиал ВолгограАского \\ госуАарственного МеАицинского университета, Российская ФеАерация
}

In the of study was investigated the antinociceptive action of derivatives of quinazolinone-4 in 187 male and 196 female rats, including females rats in the different stages of the estrous cycle: diestrus $1 / 2$ and proestrus /estrus in models of nociceptive responses induced by chemical stimuli (formalin test, «acetic cramps»), to assess the level of organization of the peripheral pain sensation. Substances (laboratory code numbers: PGFA - I, II, III, IV, V, VI, VII) at a dose of 2/10 of the molecular weight in $\mathrm{mg} / \mathrm{kg}$, reference drugs: metamizole sodium and lidocaine was administered once intraperitoneally 40 minutes before administration of chemical irritants. Control and males received respectively solubilizate Tween-80 and saline $(0.4 \mathrm{ml}$ intraperitoneally) under similar conditions. The 4-quinazolinone derivatives compounds I-IV, VI, VII were investigated as potential analgesics. Substance I-IV, VI, VII exhibited analgesic activity in male and female rats. Substances I, VI, VII have analgesic effects on female rats in phase of the estrous cycle diestrus $1 / 2$; substance I-IV, VI - in the stage of proestrus/estrus. Among the investigated derivatives of quinazolinone-4 compound VI is a leader in analgesic activity.

Keywords: derivatives of quinazolinone-4, analgesic effect, formalin test, acetic cramps

Изучалось антиноцицептивное действие производных хиназолинон-4 у 187 самцов и 196 самок крыс, в том числе у самок в стадиях эстрального цикла: диэструс $1 \frac{1}{2}$ и проэструс/эструс в формалиновом тесте, тесте «уксусные корчи». Вещества (лабораторные шифры: PGFA - I, II, III, IV, V, VI, VII) в дозе 2/10 от молекулярной массы в мг/кг, метамизол натрия и лидокаин вводили однократно внутрибрюшинно за 40 минут до введения альгогенов. Контрольные животные получали солюбилизат твина-80 и физиологический раствор. Производные хиназолинона-4 соединения I-IV, VI и VII оказались интересны в качестве потенциальных анальгетиков. Вещества I-IV, VI и VII проявляют обезболивающую активность у самцов и самок. Соединения I, VI и VII оказывают обезболивающее действие на самок крыс в фазе диэструс 1/2; вещества I-IV и VI - в стадии проэструс/эструс. Среди исследованных производных хиназолинона-4 соединение VI является лидером по анальгетической активности.

Ключевые слова: производные хиназолинона-4; обезболивающее действие, формалиновый тест, уксусные корчи 